\title{
Effects of HeLa and BHK-21 cells on the survival of fowl, bull, ram and boar spermatozoa in vitro
}

\author{
K. Ashizawa, Y. Tokudome, K. Okauchi and H. Nishiyama* \\ Laboratory of Animal Reproduction, Faculty of Agriculture, Miyazaki University, Miyazaki \\ 880 and ${ }^{*}$ Department of Animal Science, Faculty of Agriculture, Kyushu University 46-06, \\ Fukuoka 812, Japan
}

\begin{abstract}
Summary. HeLa and BHK-21 cells, which are not related immunologically to fowl cells, were cultured and the effects of these cells on the survival and fertilizing ability of fowl spermatozoa were investigated. When spermatozoa were incubated at $41{ }^{\circ} \mathrm{C}$ with these cells, sperm motility was maintained for 5-6 days. Fertilizing ability was also retained after incubation at $41^{\circ} \mathrm{C}$ for 2 days. Cultured cells also contributed to the maintenance of motility of bull and ram, but not boar, spermatozoa.
\end{abstract}

\section{Introduction}

Temperature has long been known to exert a strong influence on the motility, survival and fertilizing ability of spermatozoa (Mann, 1964). Rabbit spermatozoa soon lose their motility at $45^{\circ} \mathrm{C}$, although they are capable of surviving for several hours in vitro at $40^{\circ} \mathrm{C}$ (Walton, 1930). In domestic fowl, fertilizing ability of spermatozoa stored in Ringer's solution at $41^{\circ} \mathrm{C}$, the normal body temperature, is also lost within a few hours (Schindler, Weinstein, Moses \& Gabriel, 1955).

However, fowl spermatozoa incubated at $41^{\circ} \mathrm{C}$ with cells from the fowl oviduct, fowl kidney, the 'skeletal muscle of a 9-day chick embryo remained motile for 5-7 days and fertilizable for 2-4 days (Ashizawa, Nishiyama \& Nagae, 1976; Ashizawa \& Nishiyama, 1977; Fujihara \& Howarth, 1980). These results indicated that the use of cultured cells is effective for prolonging sperm survival, and suggest that this effect may be observed with many other sources of cultured cells.

In the present study, we investigated the effectiveness of different cells such as $\mathrm{HeLa}$ cells (Gey, Coffman \& Kubicek, 1952; cells from a line of epithelial morphology), derived from the uterine cervical carcinoma of a woman, and BHK-21 cells (MacPherson \& Stoker, 1962; cells from a line of fibroblastic morphology), derived from the kidneys of Syrian hamsters. These established cell lines are not related immunologically to fowl cells. We also studied whether the prolongation of sperm survival by this system could be applied to some mammalian spermatozoa.

\section{Materials and Methods}

Animals. The birds were White Leghorn roosters and pullets (Shaver strain) obtained from Koyu Poultry Farm (Miyazaki, Japan). The Holstein-Friesian bull and Corriedale ram were obtained from Sumiyoshi Farm (Miyazaki University) and the Hampshire boar from Miyazaki Prefectural Livestock Experiment Station (Miyazaki). All the animals were mature and normal. 
Fowl spermatozoa. Monolayer cultures of HeLa and BHK-21 cells were obtained by culturing cells in Eagle's Minimum Essential Medium supplemented with $10 \%$ newborn calf serum (Commonwealth Serum Laboratories, Victoria, Australia) at $41^{\circ} \mathrm{C}$ in $5 \% \mathrm{CO}_{2}+95 \%$ air for 3 days until they reached confluence in $2.5 \mathrm{~cm}$ Petri dishes. Kanamycin sulphate $(60 \mu \mathrm{g} / \mathrm{ml})$ was routinely added to the medium. At the same time, the cells originating from epithelia of the shell gland of the pullet oviduct were cultured under the same conditions (control 1). Cell preparations and cultures were carried out according to the method described by Ashizawa et al. (1976). On the 3 rd day of culture, the culture medium $(1 \mathrm{ml})$ was changed and spermatozoa were added to reach a sperm concentration of $2.0 \times 10^{8} / \mathrm{ml}$. The spermatozoa had been collected as aseptically as possible from several roosters by the method of Fujihara, Tanaka \& Nishiyama (1973) and washed once with culture medium by centrifuging the suspension at $500 \mathrm{~g}$ for $10 \mathrm{~min}$. The spermatozoa and cells were incubated as described above for the culture of cells alone. Spermatozoa incubated in culture medium free of their cells were used as control 2. After addition of semen, sperm motility was assessed at room temperature $\left(20-25^{\circ} \mathrm{C}\right)$ every day during the incubation period at $41^{\circ} \mathrm{C}$. The evaluation of motility was carried out by observing spermatozoa from several areas (usually 4 or 5) of the Petri dish directly from above using an inverted microscope, and their motility was scored on a 0 to 5 scale (Wheeler \& Andrews, 1943). The mean percentage of morphologically abnormal spermatozoa was determined on the 2 nd and 4th day of incubation (see Ashizawa et al., 1976). Fertilizing ability was examined using the fowl spermatozoa incubated with cultured cells or in the cell-free medium for 2 days. To test for sperm fertilizing ability $1.2 \times 10^{8}$ spermatozoa in about $0.6 \mathrm{ml}$ culture medium were inseminated into the shell gland of a pullet's oviduct by the method of Bobr, Lake, Lorenz, Ogasawara \& Krzanowska (1965). From 2 days after insemination, any eggs laid were collected, incubated and examined on the 4th day of incubation for fertility. The duration of fertility was also determined.

Bull, ram and boar spermatozoa. The HeLa and BHK-21 cells were cultured as described above. Kanamycin sulphate $(60 \mu \mathrm{g} / \mathrm{ml})$, penicillin $\mathrm{G}$ potassium (100 units $/ \mathrm{ml})$, streptomycin sulphate $(100 \mu \mathrm{g} / \mathrm{ml})$ and tetracycline hydrochloride $(50 \mu \mathrm{g} / \mathrm{ml})$ were routinely added to the medium. Mammalian spermatozoa (bull, ram and boar) and fowl spermatozoa which were collected as aseptically as possible (bull: artificial vagina; ram: electroejaculation; boar: gloved hand technique; fowl: as above) were added to the Petri dishes to reach a sperm concentration of $2.0 \times 10^{8} / \mathrm{ml}$. The boar semen used consisted of sperm-rich fractions of the ejaculates. The spermatozoa and HeLa cells or BHK-21 cells were incubated at $41^{\circ} \mathrm{C}$ (close to the fowl's body temperature) or $38^{\circ} \mathrm{C}$ (close to the bull, ram and boar's body temperature) in $5 \% \mathrm{CO}_{2}+95 \%$ air. Spermatozoa incubated in cell-free medium were used as controls. Sperm motility was assessed at room temperature $\left(20-25^{\circ} \mathrm{C}\right.$ ) every $3 \mathrm{~h}$ (mammalian spermatozoa) or $24 \mathrm{~h}$ (fowl spermatozoa) by the method described above for the evaluation of fowl sperm motility, and duration of the maintenance of motility of spermatozoa was determined. Observation of boar sperm motility was carried out after shaking of the Petri dish for 5-10 min because the spermatozoa were immotile.

\section{Results}

\section{Fowl spermatozoa}

The changes of sperm motility in the various incubation experiments are shown in Table 1. Fowl spermatozoa in the cell-free medium (control 2) lost their motility rapidly, while those incubated with cells of any source maintained their motility for 5-6 days and there were almost no differences in the effects of the 3 types of cultured cells. The numbers of morphologically abnormal spermatozoa were also lower in the incubation experiment with cultured cells than in control 2 and the differences between them were significant $(P<0.01)$ (Table 2). 
Table 1. Motility score (at room temperature, $20-25^{\circ} \mathrm{C}$ ) of fowl spermatozoa incubated with cultured cells at $41^{\circ} \mathrm{C}$ in $5 \% \mathrm{CO}_{2}+95 \%$ air

\begin{tabular}{|c|c|c|c|c|c|c|c|c|}
\hline \multirow[b]{2}{*}{ Cells } & \multicolumn{8}{|c|}{ Days after addition of spermatozoa } \\
\hline & 0 & 1 & 2 & 3 & 4 & 5 & 6 & 7 \\
\hline HeLa cells & $5 \cdot 0 \pm 0 \cdot 0$ & $4.6 \pm 0.2$ & $3.6 \pm 0.2$ & $2.8 \pm 0.4$ & $1.6 \pm 0.2$ & $1.0 \pm 0.0$ & $0.4 \pm 0.4$ & 0 \\
\hline BHK- 21 cells & $5.0 \pm 0.0$ & $4.4 \pm 0.4$ & $3.6 \pm 0.2$ & $2 \cdot 8 \pm 0.2$ & $1.4 \pm 0.6$ & $0.4 \pm 0.2$ & 0 & 0 \\
\hline $\begin{array}{l}\text { Epithelial cells of fowl } \\
\text { oviduct (control 1) }\end{array}$ & $5.0 \pm 0.0$ & $4.4 \pm 0.2$ & $3 \cdot 6 \pm 0 \cdot 2$ & $3 \cdot 0 \pm 0 \cdot 3$ & $1.4 \pm 0.2$ & $0.6 \pm 0.2$ & 0 & 0 \\
\hline None (control 2) & $5 \cdot 0 \pm 0.0$ & $3.4 \pm 0.5$ & $0.4 \pm 0.4$ & 0 & 0 & 0 & 0 & 0 \\
\hline
\end{tabular}

Each figure represents an average of 5 trials \pm s.e.m.

Table 2. The mean \pm s.e.m. (of 5 trials) percentage of morphologically abnormal fowl spermatozoa after incubation in various media for 2 or 4 days

\begin{tabular}{lcc}
\hline \multicolumn{1}{c}{ Cells } & 2 days & 4 days \\
\hline HeLa cells & $13 \cdot 4 \pm 1 \cdot 2^{\mathrm{a}}$ & $30 \cdot 2 \pm 1 \cdot 1^{\mathrm{c}}$ \\
BHK-21 cells & $13 \cdot 5 \pm 1 \cdot 6^{\mathrm{a}}$ & $35 \cdot 8 \pm 1 \cdot 3^{\mathrm{c}}$ \\
Epithelial cells of fowl oviduct (control 1) & $12 \cdot 6 \pm 0 \cdot 6^{\mathrm{a}}$ & $33 \cdot 7 \pm 1 \cdot 1^{\mathrm{c}}$ \\
None (control 2) & $88 \cdot 5 \pm 1 \cdot 5^{\mathrm{b}}$ & $90 \cdot 6 \pm 2 \cdot 2^{\mathrm{d}}$ \\
\hline
\end{tabular}

Within columns, values with different superscripts differ significantly $(P<$ $0.01)$ from each other.

The fowl spermatozoa incubated for 2 days at $41^{\circ} \mathrm{C}$ in cell-free medium had no fertilizing ability. In contrast, spermatozoa incubated with the cultured cells were highly fertile as judged by the number of fertile eggs laid during the 1 st and 2 nd week after insemination (Table 3). Fowl oviducal cells, and HeLa and BHK-21 cells exerted similar favourable effects on the maintenance of the fertilizing ability of spermatozoa.

Table 3. Fertilizing ability of fowl spermatozoa incubated with cultured cells for 2 days at $41{ }^{\circ} \mathrm{C}$ in $5 \% \mathrm{CO}_{2}+95 \%$ air

\begin{tabular}{lcccc}
\hline & No. of hens & \multicolumn{2}{c}{ Fertilized eggs (\%) } & \multirow{2}{*}{$\begin{array}{c}\text { Mean } \pm \text { s.e.m. duration } \\
\text { of fertility } \\
\text { (days) }\end{array}$} \\
\multicolumn{1}{c}{ Cells } & 4 & $95 \cdot 5(21 / 22)^{*}$ & $76 \cdot 0(19 / 25)$ & $13 \cdot 8 \pm 0 \cdot 5^{\mathrm{a}}$ \\
inseminated & 1st week & 2nd week & & \\
HeLa cells & 4 & $91 \cdot 3(21 / 23)$ & $87 \cdot 3(21 / 24)$ & $15 \cdot 0 \pm 1 \cdot 1^{\mathrm{a}}$ \\
BHK-21 cells & 4 & $95 \cdot 8(23 / 24)$ & $82 \cdot 6(19 / 23)$ & $13 \cdot 3 \pm 0 \cdot 6^{\mathrm{a}}$ \\
Epithelial cells of fowl oviduct (control 1) & 4 & $0(0 / 22)$ & $0(0 / 24)$ & $0^{\mathrm{b}}$ \\
None (control 2) & 4 & &
\end{tabular}

* Fertilizing ability was determined by the number of fertile eggs/total no. of eggs laid during each week. Within columns, values with different superscripts differ significantly $(P<0.01)$ from each other.

\section{Bull, ram and boar spermatozoa}

The results are shown in Table 4. Incubation with cultured cells prolonged the motility of bull and ram spermatozoa about 2-3 times compared with that of spermatozoa incubated in cell-free medium. The motility of boar spermatozoa could not be maintained. The survival period for mammalian spermatozoa was slightly longer at 38 than at $41^{\circ} \mathrm{C}$, but there was no difference in survival ability of fowl spermatozoa between the two temperatures. 
Table 4. Duration of the maintenance of motility of bull, ram, boar and fowl spermatozoa incubated with cultured cells at 41 or $38^{\circ} \mathrm{C}$ in $5 \% \mathrm{CO}_{2}+95 \%$ air

\begin{tabular}{lcrrrr}
\hline & & \multicolumn{4}{c}{ Duration of motility (h) } \\
\cline { 3 - 6 } \multicolumn{1}{c}{ Cells } & $\begin{array}{c}\text { Temperature } \\
\left({ }^{\circ} \mathrm{C}\right)\end{array}$ & \multicolumn{1}{c}{ Bull } & \multicolumn{1}{c}{ Ram } & Boar & Fowl \\
\hline HeLa cells & 41 & $15 \pm 2$ & $15 \pm 1$ & $15 \pm 3$ & $120 \pm 15$ \\
BHK-21 cells & 41 & $18 \pm 1$ & $15 \pm 2$ & $21 \pm 2$ & $120 \pm 11$ \\
None (control) & 41 & $6 \pm 0$ & $6 \pm 1$ & $27 \pm 2$ & $24 \pm 11$ \\
HeLa cells & 38 & $18 \pm 1$ & $27 \pm 2$ & $24 \pm 2$ & $120 \pm 13$ \\
BHK-21 cells & 38 & $18 \pm 1$ & $27 \pm 1$ & $27 \pm 2$ & $120 \pm 8$ \\
None (control) & 38 & $9 \pm 1$ & $9 \pm 0$ & $27 \pm 1$ & $24 \pm 8$ \\
\hline
\end{tabular}

Each figure represents an average of 5 trials \pm s.e.m.

\section{Discussion}

These results show that several types of cultured cells can prolong the survival of spermatozoa of the fowl and some mammals, and support the suggestion of Ashizawa et al. (1976) that an environment provided by living cells is all that is necessary for prolonged sperm survival. It seems possible that a substance or substances which are supplied by the cultured cells reach the spermatozoa by diffusion and effectively prolong their survival (Ashizawa \& Nishiyama, 1978; Fujihara \& Howarth, 1980). However, the nature of such a substance(s) is not yet understood.

We thank Dr H. Katayama, Miyazaki University, and the staff of the Miyazaki Prefectural Livestock Experiment Station for their technical assistance. This study was supported by grants from the Ministry of Education of Japan (Nos. 576167 and 56760175).

\section{References}

Ashizawa, K. \& Nishiyama, H. (1977) Effects of various cultured cells on the survival and fertilizing ability of fowl spermatozoa. J. Reprod. Fert. 49, 405-407.

Ashizawa, K. \& Nishiyama, H. (1978) Effects of proximity of spermatozoa to cultured cells on the survival of fowl spermatozoa in vitro. Jap. Poult. Sci. 15, 74-77.

Ashixawa, K., Nishiyama, H. \& Nagae, T. (1976) Effects of oviducal cells on the survival and fertilizing ability of fowl spermatozoa. J. Reprod. Fert. 47, 305-311.

Bobr, L.W., Lake, P.E., Lorenz, F.W., Ogasawara, F.X. \& Krzanowska, H. (1965) Inhibition of ovulation in the domestic hen by intrauterine insemination. Poult. Sci. 44, 659-661.

Fujihara, N. \& Howarth, B., Jr (1980) Prolonged survival of cock spermatozoa in vitro with fluid removed from tissue cultured oviducal cells. Poult. Sci. 59, 164-167.

Fujihara, N., Tanaka, K. \& Nishiyama, H. (1973) In vitro fertilization of fowl ova. Jap. J. zootech. Sci. 44, 564-568.
Gey, G.O., Coffman, W.D. \& Kubicek, M.T. (1952) Tissue culture studies of the proliferative capacity of cervical carcinoma and normal epithelium. Cancer Res. 12, 264-265.

MacPherson, I. \& Stoker, M. (1962) Polyoma transformation of hamster cell clones - an investigation of genetic factors affecting cell competence. Virology 16, 147-151.

Mann, T. (1964) Influence of ion concentration, dilution, temperature, and other extraneous factors, on semen in vitro. In The Biochemistry of Semen and of the Male Reproductive Tract, p. 356. Methuen, London.

Schindler, H., Weinstein, S., Moses, E. \& Gabriel, I. (1955) The effect of various diluents and storage times on the fertilizing capacity of cock semen. Poult. Sci. 34, 1113-1117.

Walton, A. (1930) The effect of temperature on the survival in vitro of rabbit spermatozoa obtained from the vas deferens. J. exp. Biol. 7, 201-219.

Wheeler, N.C. \& Andrews, F.N. (1943) The influence of season on semen production in the domestic fowl. Poult. Sci. 22, 361-367. 